\title{
Iron-Catalyzed Diastereoselective Synthesis of Disubstituted Morpholines via C-O or C-N Bond Formation
}

\author{
Thomas Aubineau \\ Alexandre Dupas \\ Tian Zeng \\ Janine Cossy* (D)
}

Molecular, Macromolecular Chemistry and Materials, ESPCI Paris, PSL University, CNRS, 10 Rue Vauquelin, 75005 Paris, France janine.cossy@espci.fr

In expression of our deepest gratitude to Prof. Barry M. Trost.

Published as part of the Cluster The Power of Transition Metals: An Unending Well-Spring of New Reactivity

Received: 28.04.2020

Accepted after revision: 23.06.2020

Published online: 23.07 .2020

DOI: 10.1055/s-0040-1707902; Art ID: St-2020-b0236-c

Abstract The diastereoselective synthesis of 2,6- and 3,5-disubstituted morpholines was achieved from 1,2-amino ethers and 1,2-hydroxy amines substituted by an allylic alcohol using an iron(III) catalyst. The morpholines were obtained either by $\mathrm{C}-\mathrm{O}$ or $\mathrm{C}-\mathrm{N}$ bond formation. A plausible mechanism is suggested, involving a thermodynamic equilibrium to explain the formation of the cis diastereoisomer as the major product.

Key words morpholine, iron, diastereoselective, thermodynamic equilibrium

Nitrogen- and oxygen-containing heterocycles are present in a great diversity of compounds. Morpholine, which contains these two heteroatoms, has a high industrial importance and a wide range of applications from rubber additives to optical brighteners. ${ }^{1}$ Moreover, the morpholine scaffold is frequently encountered in biologically active compounds. $^{2}$ Therefore, a variety of methods has been developed to access this heterocycle, ${ }^{3}$ such as the use of vinyl sulfonium salts along with amino alcohols, ${ }^{4}$ the ring-opening of epoxides or aziridines, ${ }^{5}$ or the electrochemical activation of $\mathrm{C}=\mathrm{C}$ double bonds. ${ }^{6}$ In the field of metal-catalyzed synthesis of morpholines, ${ }^{3 \mathrm{f}}$ several strategies have been developed depending on which bond is constructed (i.e. C-N, $\mathrm{C}-\mathrm{O}$, or $\mathrm{C}-\mathrm{C}$ bond). In particular, the formation of the $\mathrm{C}-\mathrm{O}$ bond by activation of allylic alcohols have attracted our interest. For example, Saikia et al. have described the diastereoselective synthesis of cis-2,6-disubstituted morpholines B via the activation of (Z)-allylic alcohols $\mathbf{A}$ using a Pd(II) catalyst, followed by the intramolecular addition of an alcohol. ${ }^{7}$ Bandini et al. reported a similar transformation, with the help of a cationic gold catalyst, starting from $\mathbf{C}^{8}$

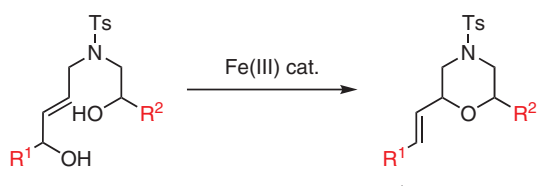

(60-97\%) cis/trans up to $95: 5$

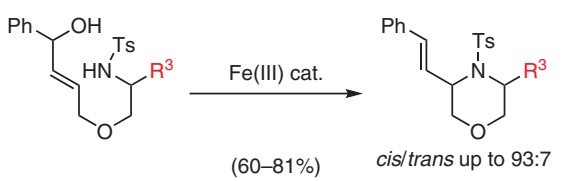

$\mathrm{R}^{1}=\mathrm{Ph}, \mathrm{Me}, \mathrm{H} ; \mathrm{R}^{2}=\mathrm{H}$, alkyl, vinyl, $\mathrm{CF}_{3}$, $\operatorname{Het}(\mathrm{Ar})$

$\mathrm{R}^{3}=\mathrm{H}$, alkyl, aryl

In the context of our studies concerning the use of iron salts for the diastereoselective synthesis of disubstituted heterocycles by activation of allylic alcohols, ${ }^{9}$ we have envisioned that iron salts like iron trichloride could also induce the formation of disubstituted morpholines $\mathbf{F}$ and $\mathbf{H}$ from the corresponding substituted amino alcohols $\mathbf{E}$ and $\mathbf{G}$ (Scheme 1)

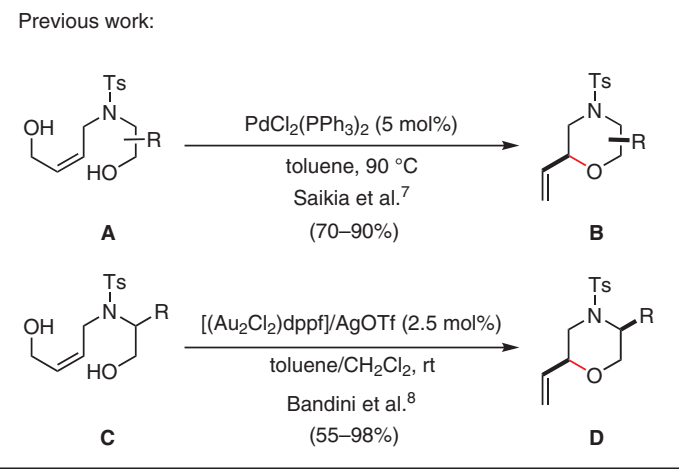

This work:

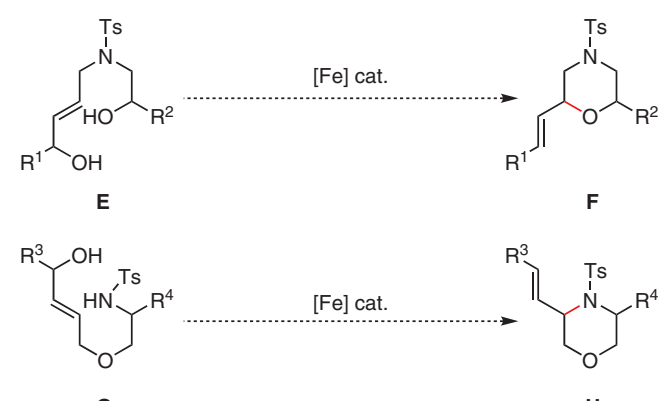

G

Scheme 1 Metal-catalyzed activation of allylic alcohols to access disubstituted morpholines 
The synthesis of the amino allylic alcohols $\mathbf{6 a}-\mathbf{i}$, precursors of 2,6-disubtituted morpholines $\mathbf{F}$, was achieved from the commercially available amino acetaldehyde dimethyl acetal 1 according to the sequence depicted in Scheme 2. After protection of the amine with a tosyl group, the sulfonamide $\mathbf{2}$ was transformed into the propargyl amine $\mathbf{3}$ in 95\% yield (propargyl bromide, $\mathrm{K}_{2} \mathrm{CO}_{3}$, acetone, reflux), which was then used as a platform to access a diversity of amino allylic alcohols 6. Deprotonation of the acetylenic moiety ( $n$-BuLi, THF) and addition of an aldehyde $\left(\mathrm{R}^{1}=\mathrm{Ph}, \mathrm{Me}, \mathrm{H}\right)$ led to the corresponding propargylic alcohols $\mathbf{4 a - c}$. Cleavage of the acetal moiety under acidic conditions (PTSA, $100{ }^{\circ} \mathrm{C}$ ) led to an aldehyde intermediate, which was transformed by addition of a nucleophile into different secondary alcohols $\mathbf{5 a}-\mathbf{i}$. Finally, the partial reduction of the acetylenic bond $\left(\mathrm{LiAlH}_{4}, \mathrm{THF}, 0^{\circ} \mathrm{C}\right.$ to rt) gave the desired allylic alcohols 6a-i. (Scheme 2)

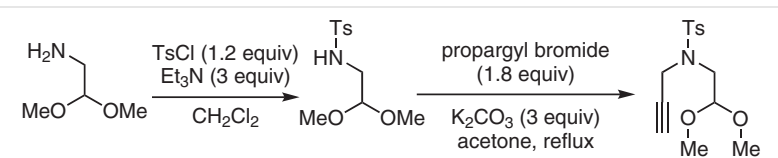

quant. 2

$295 \%$

$95 \% \quad 3$

1) n-BuLi (2.2 equiv) THF

2) $\mathrm{R}^{1} \mathrm{CHO}$ (1.2 equiv)
20-61\%

$6 a-i$

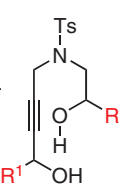

$5 a-i$
1) PTSA (1 equiv) Ts $\mathrm{MeCN} / \mathrm{H}_{2} \mathrm{O}$

$\stackrel{100^{\circ} \mathrm{C}}{\longleftarrow}$

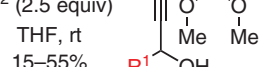

$\mathrm{R}^{1}=\mathrm{Ph}, \mathrm{Me}, \mathrm{H}$

$\mathrm{R}^{2}=\mathrm{H}, n-\mathrm{C}_{6} \mathrm{H}_{13}, \mathrm{Pr}, \mathrm{Ph}$, vinyl, $\mathrm{CF}_{3}$, 2-furyl

Scheme 2 Synthesis of the 2,6-disubstituted morpholines precursors

A second strategy was employed for the synthesis of amino allylic alcohols 10a-d precursors of 3,5-disubstituted morpholines $\mathbf{H}$. Propargyl ethers $\mathbf{8 a}-\mathbf{d}$ were obtained by the regioselective opening of monosubstituted aziridines 7a-d by the propargylic alcohol in DMSO under basic conditions ( $t$-BuOK, DMSO). ${ }^{10}$ The terminal triple bond was then functionalized by addition of the lithium acetylide on the benzaldehyde. The resultant propargyl alcohols 9a-d were partially reduced, as previously, by $\mathrm{LiAlH}_{4}$ to the corresponding allylic alcohols 10a-d (Scheme 3 ).

In order to test the heterocyclization, $\mathbf{6 a}$ was treated with $\mathrm{FeCl}_{3} \cdot 6 \mathrm{H}_{2} \mathrm{O}$ (5 mol\%) in $\mathrm{CH}_{2} \mathrm{Cl}_{2}$ at room temperature. After only 15 minutes, full conversion of $\mathbf{6 a}$ was observed, and the monosubstituted morpholine 11a was isolated in good yield (77\%) (Scheme 4).

To evaluate the diastereoselectivity, the hexyl-substituted $\mathrm{N}$-tethered amino alcohol $\mathbf{6 b}$ was first chosen for the optimization of the reaction conditions. When $\mathbf{6 b}$ was treated with $5 \mathrm{~mol} \%$ of $\mathrm{FeCl}_{3} \cdot 6 \mathrm{H}_{2} \mathrm{O}\left(\mathrm{CH}_{2} \mathrm{Cl}_{2}, 24 \mathrm{~h}\right)$ morpholine 11b

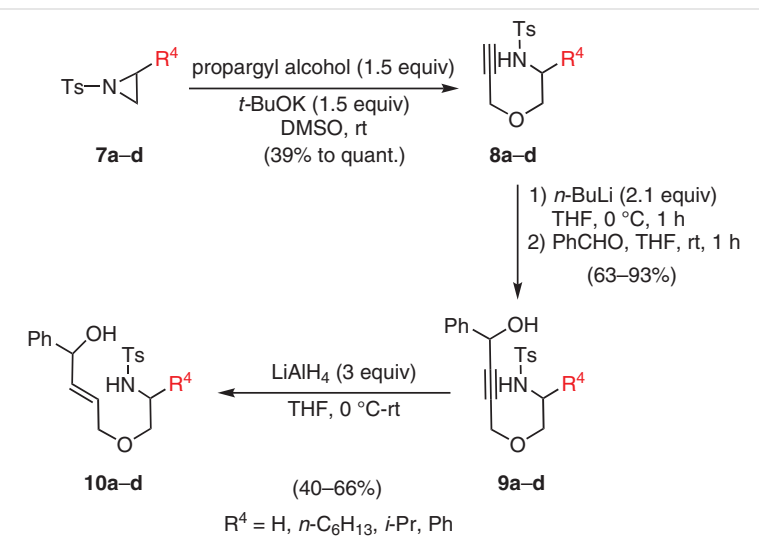

Scheme 3 Synthesis of the 3,5-disubstituted morpholines precursors

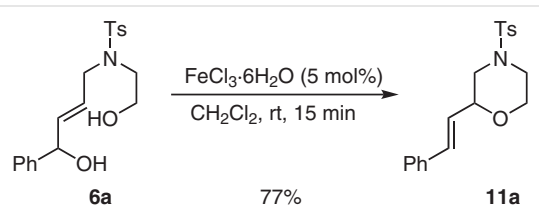

Scheme 4 Iron-catalyzed heterocyclization - formation of the $\mathrm{C}-\mathrm{O}$ bond

was obtained as a mixture of two diastereoisomers (cis/trans $=54: 46$; Table 1, entry 1 ). The same ratio was obtained with an increased catalyst loading (10 mol\%) and an extended reaction time ( $48 \mathrm{~h}$ ), while morpholine 11b was isolated in good yield ( $81 \%$; entry 2 ). The temperature of the reaction was found to be a critical parameter. Indeed, heating the reaction mixture up to $50{ }^{\circ} \mathrm{C}$ led to a great improvement of the diastereoisomeric outcome. After $15 \mathrm{~min}$ at $50{ }^{\circ} \mathrm{C}$, the cis/trans ratio was $60: 40$ and, after $2 \mathrm{~h}$, the cis diastereoisomer was obtained as the major product (cis/trans = 94:6; entries 3 and 4). Under the same conditions, other Lewis or Brønsted acids led to either low diastereoselectivity or the degradation of the products. For example, bismuth(III) triflate and indium(III) chloride efficiently catalyze the cyclization, but, in each case, the morpholine was formed as a mixture of two diastereoisomers (cis/trans = 64:36 and 54:46, respectively; entries 5 and 6). Palladium(II) acetate was, for its part, found to be totally inefficient in this transformation (entry 7). Brønsted acids were also tested. While the use of $\mathrm{HCl}$ in $\mathrm{Et}_{2} \mathrm{O}$ led to the formation of the 2,6-disubstitued morpholines albeit with no diastereoselectivity (entry 8), the use of triflic acid (TfOH) led to the complete degradation of the starting material (entry 9).

The optimized conditions were then applied to the previously synthesized amino alcohols $\mathbf{6}$ in order to access a diversity of 2,6-disubstituted morpholines. The isopropylsubstituted substrate $\mathbf{6 c}$ led to the corresponding morpholine 11c with a good yield of $77 \%$ and a high $\mathrm{dr}$ in favor of the cis diastereoisomer (cis/trans =94:6). Similarly, the trifluoromethylated morpholine 11d was isolated with a yield 
Table 1 Optimization of the Reaction Conditions to Access 2,6-Disubstuted Morpholines ${ }^{\mathrm{a}}$

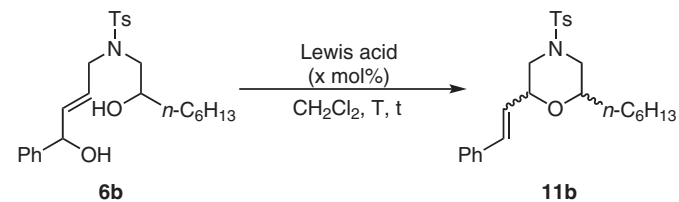

\begin{tabular}{|c|c|c|c|c|c|c|}
\hline Entry & Lewis acid & $x(\mathrm{~mol} \%)$ & Time (h) & Temp $\left({ }^{\circ} \mathrm{C}\right)$ & Yield (\%) & cis/trans $^{\mathrm{b}}$ \\
\hline 1 & $\mathrm{FeCl}_{3} \cdot 6 \mathrm{H}_{2} \mathrm{O}$ & 5 & 24 & $\mathrm{rt}$ & n.d. ${ }^{c}$ & $54: 46$ \\
\hline 2 & & 10 & 48 & rt & 81 & $54: 46$ \\
\hline 3 & & 10 & 0.25 & 50 & n.d. & $60: 40$ \\
\hline 4 & & 10 & 2 & & 82 & $94: 6$ \\
\hline 5 & $\mathrm{Bi}(\mathrm{OTf})_{3}$ & 10 & 2 & 50 & 69 & $64: 36$ \\
\hline 6 & $\operatorname{lnCl}{ }_{3}$ & 10 & 2 & 50 & 73 & $54: 46$ \\
\hline 7 & $\mathrm{Pd}(\mathrm{OAc})_{2}$ & 10 & 2 & & $-d$ & - \\
\hline 8 & $\mathrm{HCl}^{\mathrm{e}}$ & 10 & 2 & & 79 & $51: 49$ \\
\hline 9 & $\mathrm{TfOH}$ & 10 & 2 & & $-{ }^{f}$ & - \\
\hline
\end{tabular}

${ }^{\text {a }}$ Compound $\mathbf{6} \mathbf{b}$ was dissolved in $\mathrm{CH}_{2} \mathrm{Cl}_{2}$ in a tube. The Lewis acid was added to the solution, the tube was sealed, and the mixture stirred at rt or $50{ }^{\circ} \mathrm{C}$ during the specified time.

${ }^{b}$ The $\mathrm{dr}$ was measured by ${ }^{1} \mathrm{H}$ NMR spectroscopy of the crude reaction mixture after a short filtration through a plug of silica to remove the iron salts, and eluted with $\mathrm{CH}_{2} \mathrm{Cl}_{2}$.

c Not determined.

d No conversion.

${ }^{\mathrm{e}} \mathrm{HCl}$ in $\mathrm{Et}_{2} \mathrm{O}$.

${ }^{\mathrm{f}}$ Degradation of the starting material.

of $75 \%$ and a slightly lower $\mathrm{dr}$ than for 11c (cis/trans $=90: 10)$. The presence of a vinyl moiety has no influence on the reaction, as 11e was obtained in $80 \%$ yield with a cis/trans ratio of 92:8, while the phenyl-substituted

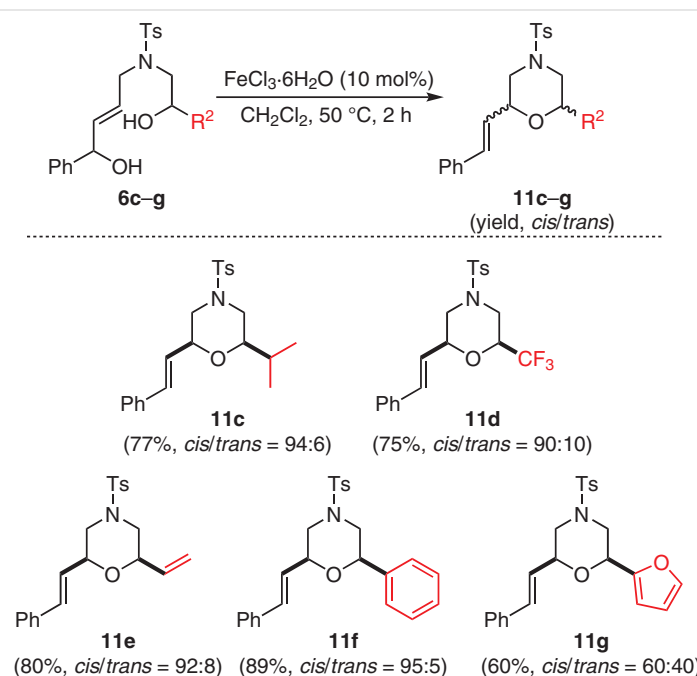

Scheme $5 \mathrm{FeCl}_{3} \cdot 6 \mathrm{H}_{2} \mathrm{O}$-catalyzed synthesis of cis-2,6-disubstituted morpholines substrate 6f led to 11f with a high yield of $89 \%$ (cis/trans $=95: 5$ ). Interestingly, a furyl-substituted morpholine 11g can also be obtained. As the furyl group tends to polymerize under the reaction conditions, the reaction was stopped after only $30 \mathrm{~min}$, which may explain the low $\mathrm{dr}$ of 11g (cis/trans $=60: 40)$ (Scheme 5).

The enantioenriched amino alcohol $(R)-\mathbf{6} \mathbf{f}^{11}$ was also involved in the heterocyclization. After $2 \mathrm{~h}$ at $50{ }^{\circ} \mathrm{C}$, the enantioenriched morpholine $(2 S, 6 R)$-11f was obtained with an excellent yield of $89 \%$, a high diastereoselectivity (cis/trans $=95: 5$ ) and a high ee of 95\% (cis diastereoisomer). ${ }^{12}$ This result shows that the stereocenter of $\mathbf{6 f}$ is recovered in $\mathbf{1 1 f}$ and that the configuration of the $\mathrm{C} 2$ stereocenter is induced by the configuration of the C6 center (Scheme 6).

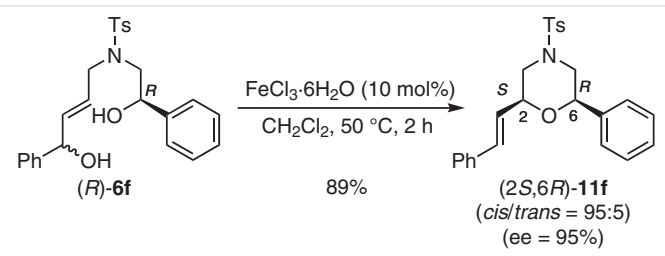

Scheme 6 Formation of an enantioenriched morpholine

To evaluate the importance of the substituent of the allylic alcohol, $\mathbf{6 h}\left(\mathrm{R}^{1}=\mathrm{Me}\right)$ and $\mathbf{6 i}\left(\mathrm{R}^{1}=\mathrm{H}\right)$ were also treated with $\mathrm{FeCl}_{3} \cdot 6 \mathrm{H}_{2} \mathrm{O}$. In dichloromethane at $50{ }^{\circ} \mathrm{C}$ for $2 \mathrm{~h}$, $6 \mathbf{h}$ was transformed to the corresponding morpholine $\mathbf{1 1 h}$ with a good yield of $80 \%$, however, without any diastereoselectivity (cis/trans $=50: 50$; Table 2 , entry 1 ). The reaction medium had to be heated up to $100{ }^{\circ} \mathrm{C}$ in dichloroethane (DCE), in a sealed tube, to obtain an excellent yield in $\mathbf{1 1 h}$ (97\%) and a cis/trans ratio of 92:8 in favor of the cis diastereoisomer (entry 2 ). Compound $\mathbf{6 i}$, incorporating a primary allylic alcohol, was subjected to similar conditions. At $50{ }^{\circ} \mathrm{C}$ in $\mathrm{CH}_{2} \mathrm{Cl}_{2}$, no cyclization occurred. At $100^{\circ} \mathrm{C}$ in DCE the vi-

Table 2 Influence of the Allylic Substitution

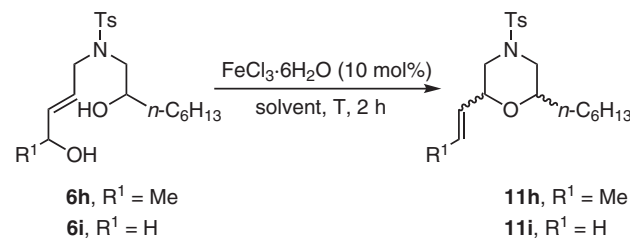

\begin{tabular}{lccccc}
\hline Entry & $\mathrm{R}^{1}$ & Solvent & Temp $\left({ }^{\circ} \mathrm{C}\right)$ & Yield (\%) & cis/trans \\
\hline 1 & $\mathrm{Me}$ & $\mathrm{CH}_{2} \mathrm{Cl}_{2}$ & 50 & 80 & $50: 50$ \\
2 & & $\mathrm{C}_{2} \mathrm{H}_{4} \mathrm{Cl}_{2}$ & 100 & 97 & $92: 8$ \\
3 & $\mathrm{H}$ & $\mathrm{CH}_{2} \mathrm{Cl}_{2}$ & 50 & $0^{\mathrm{a}}$ & - \\
4 & & $\mathrm{C}_{2} \mathrm{H}_{4} \mathrm{Cl}_{2}$ & 100 & 50 & $50: 50$ \\
\hline
\end{tabular}

a No conversion of $\mathbf{6 i}$. 
nyl-substituted morpholine $\mathbf{1 1 i}$ was isolated with a modest yield of 50\% but without any diastereoselectivity (entries 3 and 4). These results show that a stabilizing electron-donating group favors the heterocyclization and is mandatory to induce a good diastereoselectivity (vide infra).

Having demonstrated the efficiency of $\mathrm{FeCl}_{3}$ as a catalyst for the formation of 2,6-disubstituted morpholines, we hypothesized that similar conditions could be applied to adequate substrates to lead to 3,5-disubstituted morpholines. In the same manner as before, the unsubstituted amino ether 10a was treated with a catalytic amount of $\mathrm{FeCl}_{3} \cdot 6 \mathrm{H}_{2} \mathrm{O}$ (5 mol\%) in $\mathrm{CH}_{2} \mathrm{Cl}_{2}$, at room temperature. After $15 \mathrm{~min}$, the monosubstituted morpholine 12a was isolated with a good yield of $81 \%$ (Scheme 7).

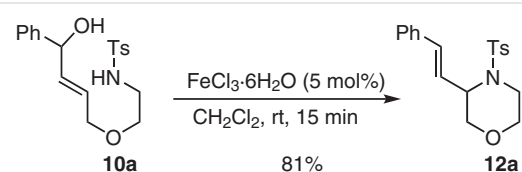

Scheme 7 Iron-catalyzed heterocyclization: formation of the $\mathrm{C}-\mathrm{N}$ bond

Compound 10b was chosen for the optimization of the reaction conditions. The amino ether was first treated with $5 \mathrm{~mol} \%$ of $\mathrm{FeCl}_{3} \cdot \mathrm{H}_{2} \mathrm{O}$ in $\mathrm{CH}_{2} \mathrm{Cl}_{2}$ (rt, $2 \mathrm{~h}$ ). Although the expected morpholine was isolated in $75 \%$ yield, analysis of the crude reaction mixture by ${ }^{1} \mathrm{H}$ NMR spectroscopy showed an unexpected cis/trans ratio of 36:64 (Table 3, entry 1 ). When the reaction was run for $168 \mathrm{~h}$, the dr slowly evolved to reach a 1 to 1 ratio of diastereoisomers (cis/trans $=52: 48$; entry 2). Increasing the catalyst loading to $10 \mathrm{~mol} \%$ resulted in an improvement of the $\mathrm{dr}$, as morpholine $\mathbf{1 2 b}$ was isolated as an 83:17 mixture of cis and trans diastereoisomers after $168 \mathrm{~h}$ (entry 3). Once again, the temperature was found to be of importance for the outcome of the cyclization. When 10b was treated with $10 \mathrm{~mol} \%$ of $\mathrm{FeCl}_{3} \cdot 6 \mathrm{H}_{2} \mathrm{O}$, in $\mathrm{CH}_{2} \mathrm{Cl}_{2}$ at $30{ }^{\circ} \mathrm{C}$ for $30 \mathrm{~h}$, a similar yield in morpholine was observed (75\%) and the dr went up to $90: 10$ in favor of the cis compound (entry 4 ). At $40{ }^{\circ} \mathrm{C}$, it took only $1 \mathrm{~h}$ to reach the full conversion of $\mathbf{1 0 b}$, and the 3,5-disubstituted morpholine 12b was formed with a good yield of $77 \%$ and with a good dr (cis/trans = 90:10; entry 5). It is worth noting that by further increasing of the temperature, a degradation of the morpholine was observed, without any change in the $\mathrm{dr}$ (entries 6 and 7). ${ }^{13}$ Other Lewis or Brønsted acids were also examined for this heterocyclization, but none of them gave as good results as iron trichloride (entries 8-11).

The optimized conditions were next applied to the previously synthesized amino ethers 10c-e. When 10c, substituted by an isopropyl group was subjected to the heterocyclization, the corresponding 3,5-disubstituted morpholine 12c was isolated with a good yield (78\%) and a good $\mathrm{dr}$ (cis/trans =93:7). The amino ether 10d, incorporating a
Table 3 Optimization of the Reaction Conditions for the Synthesis of 3,5-Disubstituted Morpholines ${ }^{\mathrm{a}}$

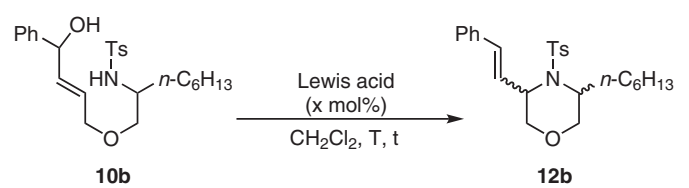

\begin{tabular}{|c|c|c|c|c|c|c|}
\hline Entry & Lewis acid & x (mol\%) & Time $(\mathrm{h})$ & Temp $\left({ }^{\circ} \mathrm{C}\right)$ & Yield (\%) & cis/trans ${ }^{\mathrm{b}}$ \\
\hline 1 & $\mathrm{FeCl}_{3} \cdot 6 \mathrm{H}_{2} \mathrm{O}$ & 5 & 2 & $\mathrm{rt}$ & 75 & $36: 64$ \\
\hline 2 & & 5 & 168 & $\mathrm{rt}$ & 75 & $52: 48$ \\
\hline 3 & & 10 & 168 & rt & 76 & $83: 17$ \\
\hline 4 & & 10 & 30 & 30 & 75 & $90: 10$ \\
\hline 5 & & 10 & 1 & 40 & 77 & $90: 10$ \\
\hline 6 & & 10 & 2.5 & 40 & n.d.c ${ }^{c}$ & $90: 10$ \\
\hline 7 & & 10 & 1 & 50 & n.d. ${ }^{c}$ & $90: 10$ \\
\hline 8 & $\mathrm{Bi}(\mathrm{OTf})_{3}$ & 10 & 2 & 40 & 70 & $90: 10$ \\
\hline 9 & $\operatorname{lnCl}{ }_{3}$ & 10 & 2 & 40 & 35 & $36: 64$ \\
\hline 10 & $\mathrm{PdCl}_{2}$ & 10 & 2 & 40 & $-{ }^{d}$ & - \\
\hline 11 & $\mathrm{HCl}^{\mathrm{e}}$ & 10 & 2 & 40 & $16^{f}$ & $36: 64$ \\
\hline
\end{tabular}

a Compound $10 \mathrm{~b}$ was dissolved in $\mathrm{CH}_{2} \mathrm{Cl}_{2}$ in a tube. The Lewis acid was added to the solution, the tube was sealed, and the mixture stirred at rt or $50{ }^{\circ} \mathrm{C}$ during the specified time.

${ }^{b}$ The dr was measured by ${ }^{1} \mathrm{H}$ NMR spectroscopy of the crude reaction mixture after a short filtration through a plug of silica plug to remove the iron salts and eluted with $\mathrm{CH}_{2} \mathrm{Cl}_{2}$.

c Not determined.

d No conversion.

e $\mathrm{HCl}$ in $\mathrm{Et}_{2} \mathrm{O}$.

${ }^{f}$ Partial degradation of the starting material or of the product.

phenyl group led, for its part, to the corresponding morpholine 12d in 70\% yield (cis/trans $=83: 17$ ). Finally, the $\alpha, \alpha$-dimethyl amino ether 10e led to the 3,5,5-trisubstituted morpholine 12e with a modest yield of $60 \%$, probably because of the steric hindrance next to the nitrogen (Scheme 8).

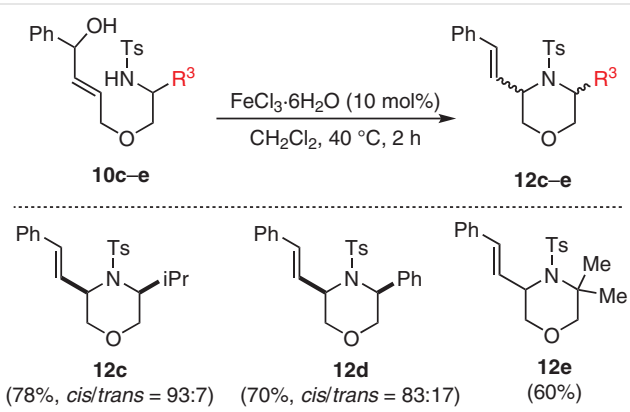

Scheme $8 \mathrm{FeCl}_{3} \cdot 6 \mathrm{H}_{2} \mathrm{O}$-catalyzed synthesis of cis-3,5-disubstituted morpholines

During the optimization process, it has been highlighted that the $\mathrm{dr}$ evolves with time, suggesting an equilibration process (Table 1, entries 3 and 4; Table 3 entries 1 and 2). The results obtained with substrates $\mathbf{6 h}$ and $\mathbf{6 i}$, bearing different substituents at the allylic position, suggest that the 

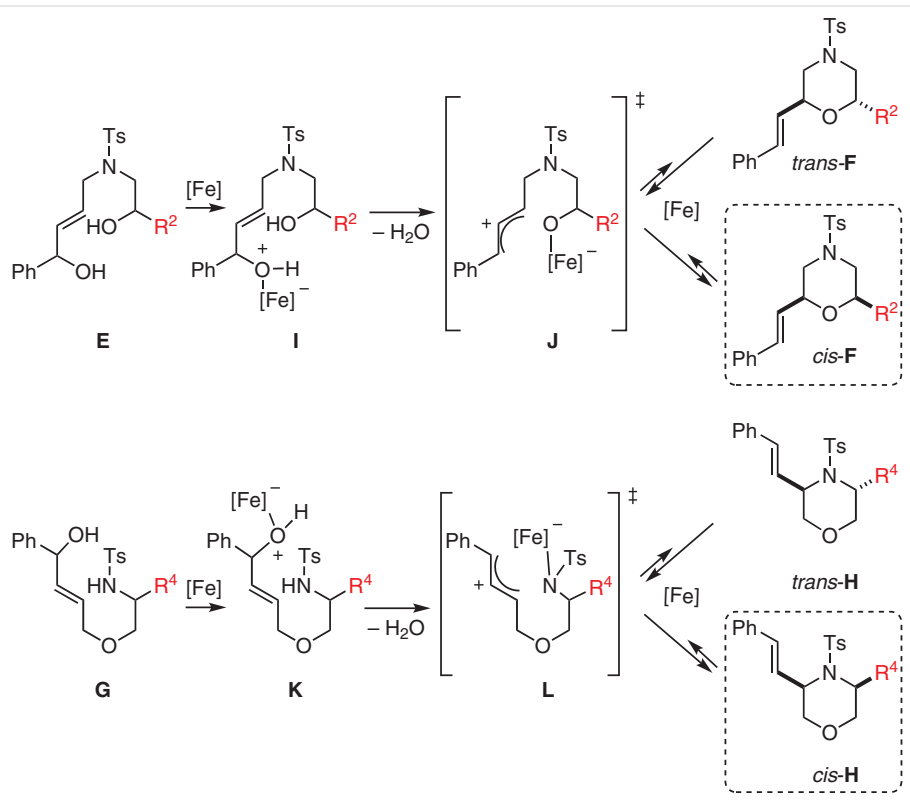

Scheme 9 Plausible mechanisms for the iron-catalyzed heterocyclization

presence of an electron-donating group is required to produce morpholines in good yields and diastereoselectivity (Table 2). Thus, it may be hypothesized that the cyclization process proceeds through a carbocation. From our previous results in iron-catalyzed heterocycle synthesis, ${ }^{9}$ the following mechanism could be proposed for both the 2,6- and the 3,5-disubstitued morpholines. The activation of the allylic alcohols $\mathbf{E}$ and $\mathbf{G}$ by $\mathrm{FeCl}_{3}$ could promote the loss of water and the formation of a delocalized carbocation ( $\mathbf{J}$ and $\mathbf{L}$ ), stabilized by the substituent of the allylic alcohol. The intramolecular attack of the oxygen or the nitrogen would lead to the morpholines $\mathbf{F}$ and $\mathbf{H}$, respectively, as a mixture of cis and trans diastereoisomers. At this point, an iron-induced thermodynamic equilibrium could take place, by a ring-opening/ring-closing process, toward the formation of the more stable cis diastereoisomer. This equilibrium would be even easier if the carbocation is stabilized by an electron-donating group, explaining why a better diastereoselectivity is observed when starting from benzylic allylic alcohols rather than methyl- or unsubstituted allylic alcohols (Scheme 9).

To explain why the cis diastereoisomer is always predominant after the thermodynamic equilibrium, the relative stability of each of the two diastereoisomers has to be compared, regarding the spatial orientation of their substituents. In the case of the 2,6-disubstituted morpholines $\mathbf{F}$, the cis diastereoisomer, whose two substituents stand in an equatorial position, is more stable than the trans diastereo- isomer. Indeed, in the trans diastereoisomer, one of the two substituents has to be axial, thus generating unfavorable 1,3-diaxial interactions with the hydrogen at C6 (Scheme 10).

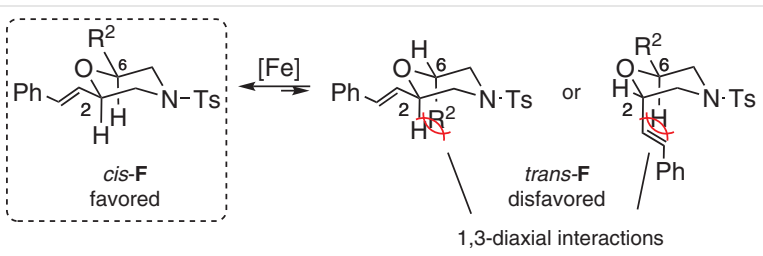

Scheme 10 Relative stability of cis and trans diastereoisomers in 2,6disubstituted morpholines

Regarding the 3,5-disubtituted morpholine $\mathbf{H}$, a similar reasoning can be applied. However, the presence of the $N$ tosyl group has to be considered (Scheme 11). Indeed, it has been described that the $\mathrm{N}-\mathrm{S}$ bond in sulfonamides has a partial double bond character. ${ }^{14 a}$ Crystallographic data previously obtained for 2,6-disubstituted $N$-tosyl piperidines also suggest that the $\mathrm{SO}_{2}$ moiety is in an equatorial position. ${ }^{14 \mathrm{~b}}$ Therefore, substituents $\alpha$ to the nitrogen may promote 1,3-allylic interactions with the $N$-tolyl group if they stand in an equatorial position. ${ }^{15}$ For this reason, a cis diaxial diastereoisomer would be more stable than a trans one, in spite of diaxial interactions between the $\mathrm{R}^{3}$ group at $\mathrm{C} 5$ and the styrenyl group at C3. Actually, this steric interaction may be the cause of the lower dr observed for 3,5compared to 2,6-disubstituted morpholines as the difference in energy between the two diastereoisomers may be smaller. 


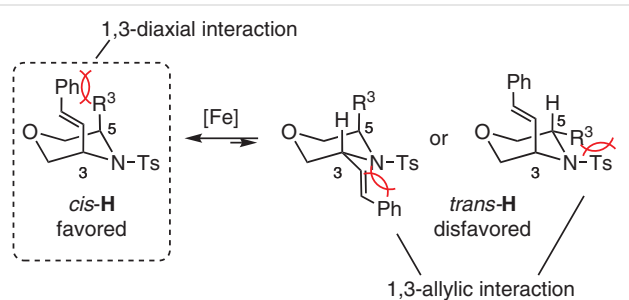

Scheme 11 Relative stability of cis and trans diastereoisomers in 3,5disubstituted morpholines

Postfunctionalization of the synthesized 2,6-disubstituted morpholines $\mathbf{1 1}$ was then envisaged. The amino moiety in $\mathbf{1 1 b}$ can be deprotected with magnesium powder under ultrasonic activation ${ }^{16}$ leading to morpholine $\mathbf{1 3}$ in good yield (88\%). It is worth noting that the $\mathrm{dr}$ remains intact during this process. The styrenic double bond can also be transformed to introduce a new substituent on the morpholine ring. Oxidative cleavage under classical conditions $\left(\mathrm{OsO}_{4}\right.$, NMO then $\mathrm{NaIO}_{4}$ ) followed by the reduction of the subsequent aldehyde $\left(\mathrm{NaBH}_{4}\right.$, EtOH) led to the primary alcohol 14 with an excellent yield (82\% from 11b; Scheme 12). ${ }^{17}$

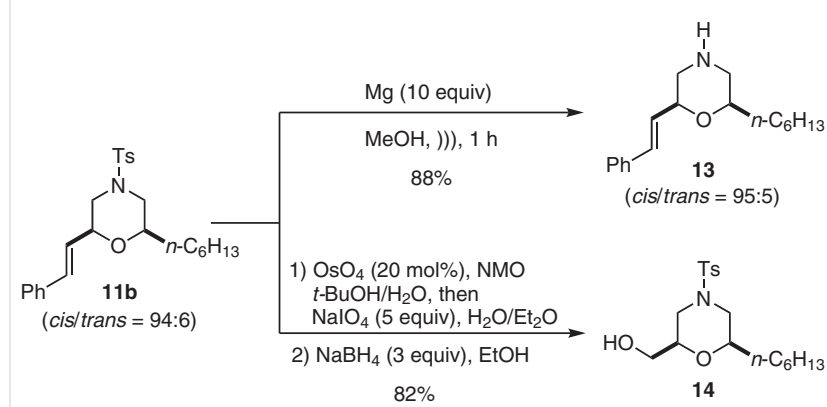

Scheme 12 Synthetic transformations of the 2,6-disubstituted morpholine 11b

Similarly, 3,5-disubstituted morpholines can be postfunctionalized. The amino group in $\mathbf{1 2 b}$ can be deprotected using the same conditions as before $(\mathrm{Mg}, \mathrm{MeOH}$, ultrasound) to produce the secondary amine $\mathbf{1 5}$ in $66 \%$ yield (cis/trans $=91: 9) .{ }^{18}$ The styrenyl moiety can also be cleaved under oxidative conditions $\left(\mathrm{OsO}_{4}, \mathrm{NMO}\right.$ then $\left.\mathrm{NaIO}_{4}\right)$ and the primary alcohol $\mathbf{1 6}$ was obtained after reduction of the resulting aldehyde $\left(\mathrm{NaBH}_{4}, \mathrm{EtOH}\right)$ with a yield of $67 \%$ (from 12b) and with an unchanged cis/trans ratio of 90:10 (Scheme 13).

Iron trichloride has been successfully used for the synthesis of both 2,6- and 3,5-disubtituted morpholines by promoting the formation of either a $\mathrm{C}-\mathrm{O}$ or a $\mathrm{C}-\mathrm{N}$ bond. This catalyst constitutes a cheap and environmentally benign alternative to palladium and gold catalysts. In each case, the substituted morpholines were isolated mostly as cis diastereoisomers, as the result of a thermodynamic

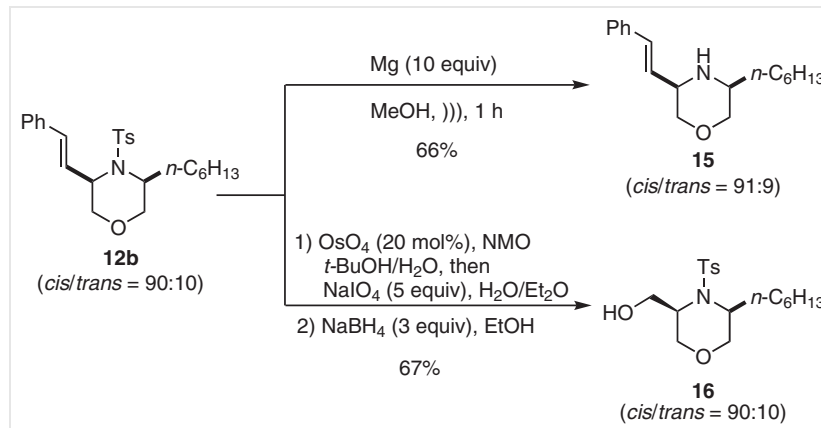

Scheme 13 Synthetic transformations of the 3,5-disubstituted morpholine 12b

equilibrium occurring by a ring-opening/ring-closing process. ${ }^{19}$ Post-transformations of the obtained morpholines were also achieved, showing that they can be used as a platform to access libraries of complex molecules.

\section{Supporting Information}

Supporting information for this article is available online at https://doi.org/10.1055/s-0036-1707902.

\section{References and Notes}

(1) Mjos, K. In Kirk-Othmer Encyclopaedia of Chemical Technology, 3rd ed., Vol. 2; Wiley Interscience: New York, 1978, 295-308.

(2) Vitaku, E.; Smith, D. T.; Njardarson, J. T. J. Med. Chem. 2014, 57, 10257.

(3) For reviews on the synthesis of morpholines and derivatives, see: (a) Pal'chikov, V. A. Russ. J. Org. Chem. 2013, 49, 787. (b) Wijtmans, R.; Vink, M.. K. S.; Schoemaker, H. E.; van Delft, F. L.; Blaauw, R. H.; Rutjes, F. P. J. T. Synthesis 2004, 641. (c) Trstenjak, U.; Ilaš, J.; Kikelj, D. Synthesis 2012, 44, 3551. (d) Varela, J.; Saá, C. Synthesis 2016, 48, 3470. (e) Palchykov, V. A.; Chebanov, V. A. Chem. Heterocycl. Compd. 2019, 55, 324. (f) Aubineau, T.; Cossy, J. Chem. Eur. J. 2019, 46, 7513. (g) Tzara, A.; Xanthopoulos, D.; Kourounakis, A. P. ChemMedChem 2020, 15, 392.

(4) Yar, M.; Fritz, S. P.; Gates, P. J.; McGarrigle, E. M.; Aggarwal, V. K. Eur. J. Org. Chem. 2012, 160.

(5) (a) Jiao, P.-F.; Zhao, B.-X.; Wang, W.-W.; He, Q.-X.; Wan, M.-S.; Shin, D.-S.; Miao, J.-Y. Bioorg. Med. Chem. Lett. 2006, 16, 2862. (b) Wang, L.; Liu, Q.-B.; Wang, D.-S.; Li, X.; Han, X.-W.; Xiao, W.J.; Zhou, Y.-G. Org. Lett. 2009, 11, 1119.

(6) Claraz, A.; Courant, T.; Masson, G. Org. Lett. 2020, 22, 1580.

(7) Borah, M.; Borthakur, U.; Saikia, A. K. J. Org. Chem. 2017, 82, 1330.

(8) Bandini, M.; Monari, M.; Romanello, A.; Tragni, M. Chem. Eur. J. 2010, 16, 14272.

(9) Cornil, J.; Gonnard, L.; Bensoussan, C.; Serra-Muns, A.; Gnamm, C.; Commandeur, C.; Commandeur, M.; Reymond, S.; Guérinot, A.; Cossy, J. Acc. Chem. Res. 2015, 48, 761.

(10) Nyasse, B.; Grehn, L.; Ragnarsson, U. Chem. Commun. 1997, 11, 1017.

(11) See the Supporting Information for the synthesis of substrate (R)-6f. 
(12) The ee has been measured by chiral SFC of the 2-hydroxymethylenic morpholine obtained after oxidative cleavage of the styrenic moiety.

(13) Attempts to favor the formation of the trans diastereoisomer at temperature lower than rt were unsuccessful.

(14) (a) Modaressi-Alam, A. R.; Amirazizi, H. A.; Bagheri, H.; Bijanzadeh, H.-R.; Kleinpeter, E. J. Org. Chem. 2009, 74, 4740. (b) Guérinot, A.; Serra-Muns, A.; Gnamm, C.; Bensoussan, C.; Reymond, S.; Cossy, J. Org. Lett. 2010, 12, 1808; the possibility to have the $\mathrm{SO}_{2}$ group in an axial position cannot be totally ruled out.

(15) This has been observed on piperidines substrates. See for example: (a) Cariou, C. A. M.; Snaith, J. S. Org. Biomol. Chem. 2006, 4, 51. (b) Toumieux, S.; Compain, P.; Martin, O. R.; Selkti, M. Org. Lett. 2006, 8, 4493. (c) Kishore Vandavasi, J.; Hu, W.-P.; Chandru Senadi, G.; Chen, H.-T.; Chen, H.-Y.; Hsieh, K.-C.; Wang, J.-J. Adv. Synth. Catal. 2015, 357, 2788.

(16) Nyasse, B.; Grehn, L.; Ragnarsson, U. Chem. Commun. 1997, 11, 1017.

(17) The cis/trans ratio could not be measured because of overlapping signals in the ${ }^{1} \mathrm{H}$ NMR spectrum.

(18) Measured by GC/MS analysis of the crude mixture.

(19) Experimental Procedure for the Synthesis of 2,6- or 3,5Disubstituted Morpholines

In a tube was added the amino alcohol in $\mathrm{CH}_{2} \mathrm{Cl}_{2} \cdot \mathrm{FeCl}_{3} \cdot 6 \mathrm{H}_{2} \mathrm{O}$ was then added to the solution, the tube was sealed, and the mixture was heated at the specified temperature for 1-2 h. After cooling, the suspension was filtered through a short plug of silica gel, and elution was achieved with $\mathrm{CH}_{2} \mathrm{Cl}_{2}$ to remove the iron salts. The filtrate was concentrated under vacuum to afford the morpholine which was in most cases recovered as a pure product. Purification by flash chromatography on silica gel was performed if needed.

cis-(E)-2-Isopropyl-6-styryl-4-tosylmorpholine (10c)

${ }^{1} \mathrm{H}$ NMR $\left(400 \mathrm{MHz}, \mathrm{CDCl}_{3}\right): \delta=7.64(\mathrm{~d}, J=8.1 \mathrm{~Hz}, 2 \mathrm{H}), 7.40-7.18$ (m, $7 \mathrm{H}), 6.73-6.59(\mathrm{~m}, 1 \mathrm{H}), 6.06(\mathrm{dd}, J=16.1,5.6 \mathrm{~Hz}, 1 \mathrm{H})$, 4.29-4.19 (m, $1 \mathrm{H}), 3.68\left(\mathrm{~d}_{\mathrm{app}}, J=11.3 \mathrm{~Hz}, 2 \mathrm{H}\right), 3.41-3.29(\mathrm{~m}, 1$ $\mathrm{H}), 2.43(\mathrm{~s}, 3 \mathrm{H}), 2.05\left(\mathrm{dd}_{\mathrm{app}}, J=21.7,10.8 \mathrm{~Hz}, 2 \mathrm{H}\right), 1.77-1.65(\mathrm{~m}$, $1 \mathrm{H}), 0.98(\mathrm{~d}, J=6.8 \mathrm{~Hz}, 3 \mathrm{H}), 0.93(\mathrm{~d}, J=6.8 \mathrm{~Hz}, 3 \mathrm{H}) .{ }^{13} \mathrm{C}$ NMR $\left(100 \mathrm{MHz}, \mathrm{CDCl}_{3}\right): \delta=143.9,136.3,132.3,132.1,129.8$ (2 C), 128.6 (2 C), 128.0, 127.8 (2 C), 126.6 (2 C), 126.1, 80.1, 75.6, 50.0, 47.7, 31.6, 21.6, 18.6, 18.4. MS (EI, $70 \mathrm{eV}): \mathrm{m} / z$ (abundance) $=385\left(3, \mathrm{M}^{+*}\right), 281(14), 230$ (29), 130 (16), 129 (12), 115 (10), 98 (100), 91 (30), 69 (16), 56 (16). HRMS: $\mathrm{m} / z$ calcd for $\mathrm{C}_{22} \mathrm{H}_{28^{-}}$ $\mathrm{NO}_{3} \mathrm{~S}[\mathrm{M}+\mathrm{H}]^{+}:$386.1784; found: 386.1789 .

cis-(E)-3-Isopropyl-5-styryl-4-tosylmorpholine (12c)

${ }^{1} \mathrm{H}$ NMR $\left(400 \mathrm{MHz}, \mathrm{CDCl}_{3}\right): \delta=7.76(\mathrm{~d}, J=8.2 \mathrm{~Hz}, 2 \mathrm{H}), 7.38-7.19$ $(\mathrm{m}, 7 \mathrm{H}), 6.67(\mathrm{dd}, J=16.2,1 \mathrm{H}), 6.56-6.41(\mathrm{~m}, 1 \mathrm{H}), 4.45-4.35$ $(\mathrm{m}, 1 \mathrm{H}), 3.92(\mathrm{~d}, J=11.8 \mathrm{~Hz}, 1 \mathrm{H}), 3.87(\mathrm{~d}, J=12.0 \mathrm{~Hz}, 1 \mathrm{H}), 3.38$ (dd, $J=10.9,3.4 \mathrm{~Hz}, 1 \mathrm{H}$ ), 3.20 (dd, $J=11.9,4.0 \mathrm{~Hz}, 1 \mathrm{H}$ ), 3.11 (dd, $J=12.0,3.6 \mathrm{~Hz}, 1 \mathrm{H}), 2.43(\mathrm{~s}, 3 \mathrm{H}), 2.32-2.23(\mathrm{~m}, 1 \mathrm{H}), 1.05$ $(\mathrm{d}, J=6.7 \mathrm{~Hz}, 3 \mathrm{H}), 0.94(\mathrm{~d}, J=6.7 \mathrm{~Hz}, 3 \mathrm{H}) .{ }^{13} \mathrm{C}$ NMR $(100 \mathrm{MHz}$, $\mathrm{CDCl}_{3}$ ): $\delta=143.4,138.7,136.6,132.8,130.0$ (2 C), 128.7 (2 C), 127.9, 127.7, 127.0 (2 C), 126.5 (2 C), 69.1, 66.6, 59.6, 52.9, 28.4, 21.6, 20.6, 20.2. MS (EI, $70 \mathrm{eV}): \mathrm{m} / z$ (abundance) $=342(23), 268$ (19), 187 (11), 171 (16), 156 (12), 155 (37), 130 (16), 129 (26), 128 (11), 117 (33), 115 (27), 91 (100), 69 (14), 65 (15). HRMS: $\mathrm{m} / \mathrm{z}$ calcd for $\mathrm{C}_{22} \mathrm{H}_{27} \mathrm{NNaO}_{3} \mathrm{~S}[\mathrm{M}+\mathrm{Na}]^{+}$: 408.1604; found: 408.1606 . 